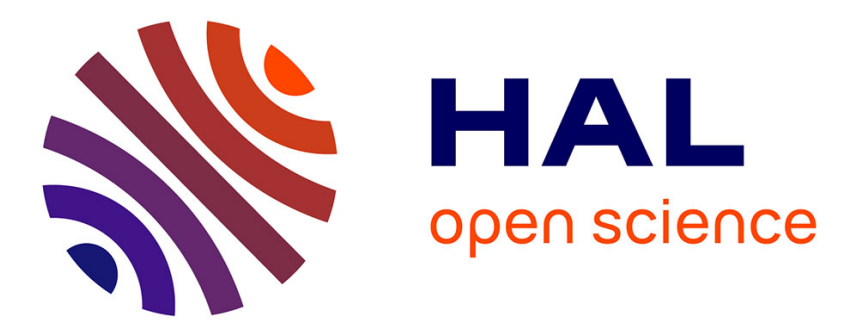

\title{
Co-operative ties and the impact of external factors upon innovation in an industrial district: some insights from the North Staffordshire Table and Giftware sector
}

Philip Robert Tomlinson, Ian Jackson

\section{- To cite this version:}

Philip Robert Tomlinson, Ian Jackson. Co-operative ties and the impact of external factors upon innovation in an industrial district: some insights from the North Staffordshire Table and Giftware sector. Regional Studies, 2011, pp.1. 10.1080/00343404.2011.585148 . hal-00724179

HAL Id: hal-00724179

https://hal.science/hal-00724179

Submitted on 19 Aug 2012

HAL is a multi-disciplinary open access archive for the deposit and dissemination of scientific research documents, whether they are published or not. The documents may come from teaching and research institutions in France or abroad, or from public or private research centers.
L'archive ouverte pluridisciplinaire HAL, est destinée au dépôt et à la diffusion de documents scientifiques de niveau recherche, publiés ou non, émanant des établissements d'enseignement et de recherche français ou étrangers, des laboratoires publics ou privés. 


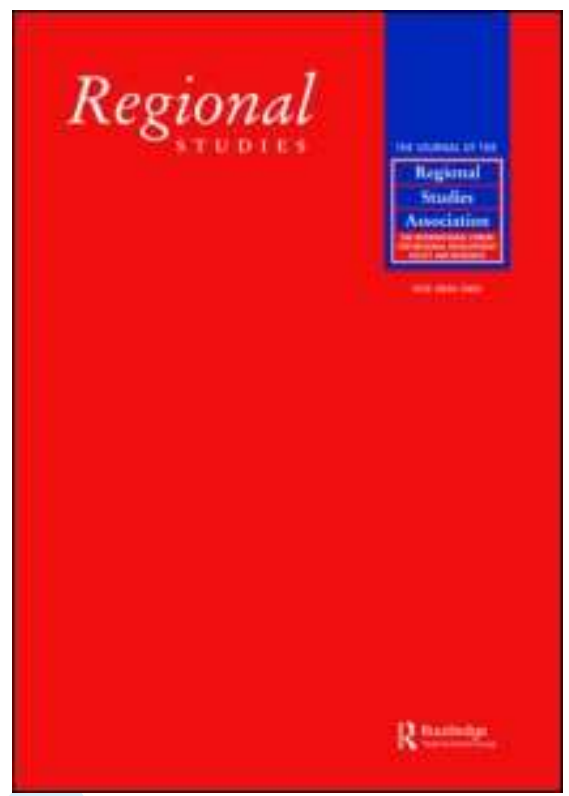

\section{Co-operative ties and the impact of external factors upon innovation in an industrial district: some insights from the North Staffordshire Table and Giftware sector}

\begin{tabular}{|c|l|}
\hline Journal: & Regional Studies \\
\hline Manuscript ID: & CRES-2010-0036.R1 \\
\hline Manuscript Type: & Main Section \\
\hline JEL codes: & $\begin{array}{l}\text { L67 - Other Consumer Nondurables: Clothing, Textiles, Shoes, and } \\
\text { Leather < L6 - Industry Studies: Manufacturing < L - Industrial } \\
\text { Organization, O18 - Regional, Urban, and Rural Analyses < O1 - } \\
\text { Economic Development < O - Economic Development, } \\
\text { Technological Change, and Growth, R58 - Regional Development } \\
\text { Policy < R5 - Regional Government Analysis < R - Urban, Rural, } \\
\text { and Regional Economics }\end{array}$ \\
\hline Keywords: & $\begin{array}{l}\text { Innovation, Co-operation, Industrial Districts, Institutions, Table } \\
\text { and Giftware }\end{array}$ \\
\hline \hline
\end{tabular}

\section{SCHOLARONE \\ Manuscripts}




\title{
Co-operative ties and the impact of external factors upon innovation in an industrial district: some insights from the North Staffordshire Table and Giftware sector
}

\author{
Philip R. Tomlinson \\ School of Management, University of Bath (UK) \\ Ian Jackson \\ Business School, Staffordshire University (UK)
}

\section{Address for Correspondence:}

School of Management

University of Bath

Bath, BA2 7AY

Tel: $+44(0) 1225383798$

Fax: +44 (0) 1225386473

Email: P.R.Tomlinson@bath.ac.uk

(Received January 2010: in revised form April 2011)

\begin{abstract}
Drawing upon a sample of 118 firms, this paper explores the impact of co-operative ties and the role of institutions upon innovation in the UK ceramic table and giftware sector. We find that locational economies are important for aiding innovation, with firms in the North Staffordshire industrial district holding an inherent advantage vis-à-vis non district firms. However while close vertical ties enhance innovation, recent concerns have arisen that horizontal collaboration between district and Asian firms is having a detrimental impact upon innovative capacity within the district. Finally institutions also appear to play an important role in facilitating the innovation process.
\end{abstract}

Keywords: Innovation, Co-operation, Industrial districts, Institutions, Table and giftware.

JEL Codes: L67, O18 and R58

\section{Introduction}

Amid concerns of globalisation and the threats posed by low cost competition, there is currently widespread acceptance in both academic and regional policy circles that the 
survival and future prosperity of Europe's old and traditional industrial districts is best attained through seeking a high road to development, one primarily based upon continuous innovation and higher value added activities (see Pyke and Sengenberger, 1992, Kaplinsky and Readman, 2001). Aligned to this view is that the innovation process itself is no longer confined within the sole domain of the firm, but rather is enhanced through greater associative and co-operative ties between firms as well as with institutions which aid $\begin{array}{lllll}\text { information } \quad \text { and } \quad \text { knowledge } & \text { transfers } \quad \text { (Lundvall, }\end{array}$ ${ }^{1}$. Within this context, a specific research question arises as to whether such collaborative ties are likely to be particularly germane for innovative performance where firms are geographically proximate in the same or related industries, such as in industrial districts or regional clusters (see Bailey and De Propris, 2009a and 2009b). This, of course, has given rise to an extensive literature on the concept of 'learning regions' and 'regional innovation systems' (see for instance, Cooke and Morgan, 1994, 1998; Morgan, 1997, 2004).

A particular case is the UK ceramics industry and the North Staffordshire table and giftware industrial district, which has borne the brunt of increasing global competition over the last decade (see Sacchetti and Tomlinson, 2009). In line with the academic literature on clusters, regional policy directives primarily from the West Midlands Regional Development Agency have focused upon creativity and raising innovative performance, advocating in particular that North Staffordshire's district firms be more open to forming co-operative ties both within and outside the district and also to other external sources of innovation such as institutions (see North Staffordshire Taskforce of the West Midlands RDA, 2003). A recently commissioned report by the consulting firm, SQW Consulting (2009) has also echoed similar sentiments. 
In the UK, studies of innovation in traditional industries such as ceramics are relatively rare, despite evidence that the sector has been highly innovative not only historically, but also in recent decades (Warren et al., 2000) ${ }^{2}$. For its continued survival in the UK and particularly the long term viability of the North Staffordshire district, both creative designs and products and smart processes within the industry are considered to be crucial. Thus identifying and gauging the impact of some of the (external) factors affecting innovative performance within the sector is of prime (regional) policy importance, while also contributing to the wider literature on regional innovation and development. In this paper, we therefore primarily explore the impact of co-operative ties upon innovation in the UK table and giftware sector; in doing so we also assess the impact of other external factors such as institutions and the district effect.

In conducting our research, this paper employs a mixed methodological approach. First, we use survey data from 118 firms within the sector and employ multivariate analysis to assess the magnitude of co-operative ties, the role of institutions and the district effect upon firms' innovative performance. The sample is split between district and non-district firms. This not only mirrors the population of table and giftware firms in the UK as a whole, but it allows us to capture district specific effects and ascertain as to whether or not the impact of cooperation over innovation is unique to the North Staffordshire district. Secondly, we draw upon insights from a series of interviews conducted with Managing Directors of UK table and

giftware firms plus related suppliers from within the district that explored co-operative ties and innovation. These insights are used to supplement our quantitative analysis. 
The remainder of this paper is set out as follows. Section (2) provides a review of the literature in relation to co-operative ties and regional innovation systems. Section (3) provides some background information and context on the UK table and giftware industry and in particular the North Staffordshire district. Section (4) outlines the research methodology and details of the sample. In Section (5), we outline the model specification and provide details of variable construction and descriptive statistics. Section (6) discusses the quantitative results, in light of observations from the interviews, while finally Section (7) concludes.

\section{Co-operative Networks, Districts and Innovation}

\subsection{Context}

Whether through vertical ties or (in some cases) horizontal links, it is now generally accepted that firms can improve their innovative performance through inter-firm exchange and coordination of resources and associated synergies in both production and organisation. Early research by Von Hippel (1976, 1988), for instance, demonstrated how end users played a crucial role in product innovation in industry, while Hakansson (1987) considered innovation and technical advance to be a product of network ties, particularly those involving both buyers and suppliers where competences are generally quite complementary. Indeed, close collaboration in supply chains often facilitates knowledge transfer between users and suppliers and the adoption and adaptation of new standards within the industry, while feedback loops allow for the refinement of products and/or processes (Tether, 2002) 3.

The emphasis upon knowledge transfer in such ties is particularly relevant since many authors regard knowledge, specifically new sources of knowledge, as the key resource in the innovation process (Spender, 1996). This is highlighted in the 'National Innovations 
Systems' approach of Lundvall (1992, 1995), where knowledge is regarded as a strategic resource and interactive learning with partner firms and/or an array of other institutions is considered a critical process for generating further knowledge, innovation and competitive advantage (see also Lundvall and Johnson, 1994). However, while access to a variety of knowledge sources generally widens firms' innovative possibilities, a critical juncture is the extent to which firms can successfully utilise such sources with their own resource capabilities (Cohen and Levinthal, 1990; Kogut and Zander, 1992). Moran and Ghosal (1996) for instance, regard more innovative firms as being able to combine new knowledge sources with novel redeployments of their existing resources, so as to generate new products and production processes. In reality, the ability of firms to exploit such opportunities will differ across firms and industries. Firms are largely heterogeneous actors and differ in their resource capacities and ability to process and utilise external sources of information and this is reflected in their relative innovative performance (see also Dyer and Singh, 1998, Inkpen and Tsang, 2005, Sammarra and Biggiero, 2008).

\subsection{Regional agglomeration and 'The District Effect'}

Over the last decade and a half, the literature on exploiting external sources of knowledge and interactive learning has held particular resonance within regional policy circles, where there has been a focus upon promoting 'learning regions' and/or 'innovative milieu' for generating economic growth (see Cooke and Morgan, 1994, 1998; Camagni, 1991; Maillat, 1995; Boekema et al., 2000). Much of this regional approach draws inspiration from the earlier noted success of the Italian industrial districts (see, for instance, Becattini, 1990; Bellandi 2003) and behind the 'learning regions' concept is again the idea that innovation is very much a social process involving the systemic exchange and enhancement of knowledge between firms and also related institutions within the region. However, whereas in the strategic management literature the unit of analysis is largely upon the firm and its associated 
networks (which are often demarcated in a non-territorial way), the regional approach emphasises the importance of co-location for innovation. This leads to an implicit assumption of a degree of homogeneity existing among firms, whereby co-located firms systemically benefit from the Marshallian 'industrial atmosphere' existing within the district and/or region.

A salient feature in this regard is that co-located firms benefit from tacit knowledge flows such as specific know-how, skills and competencies, which are often confined within the regional vicinity or closed networks (see Hudson, 1999; Sacchetti, 2004) 4. The main factors facilitating tacit knowledge flows include the mobility of local labour (including management and research staff) bringing their ideas and experiences to different firms and new start-up firms, initiated by industry researchers or employees based within the locality (Molina Morales and Martinez-Fernandez, 2006). While it is again the case that not all (locally-based) firms will utilise tacit knowledge effectively ${ }^{5}$, it is likely the diffusion of knowledge will be more pronounced at the local and regional level. This is the conclusion in the early work of Jaffe et.al (1993), who found that US domestic patent citations (a measure of innovation) tended to be (disproportionately) localised within the same state as the originating patent and that these citations tend to come sooner (than citations outside the state); they also find that while localisation effects fade over time, this occurs only very slowly. ${ }^{6}$ More recently, Griffith et.al (2006) find that by investing in R\&D facilities in the USA, UK affiliates are able to benefit from being geographically close to the latest US advances in new technology and innovation, thus highlighting the importance of proximity to take advantage of tacit knowledge flows and spillovers. In short, geographical proximity is seen to facilitate tacit knowledge diffusion potentially benefitting all firms (and aiding innovation) within the locality; within industrial districts, this is sometimes referred to as the 'district effect'. 
H1: Firms located within the district are more likely to benefit in terms of higher innovative performance than non-district based firms

\subsection{Co-operative Ties and Innovation}

A key facet in facilitating wider interaction is the degree to which firms engage in inter-firm co-operative ties. Within a district, physical proximity opens up wider possibilities for such interaction and the exchange of resources and knowledge, through both formal and informal channels and particularly between buyers and suppliers (Cooke et al., 1997). This was often the case in the traditional Italian industrial districts where a myriad of vertical and horizontal ties existed between firms, who appeared to simultaneously co-operate and compete with each other on different levels. In terms of co-operation, the co-sharing of information and resources between firms, was widely perceived as being a key source of innovation and competitive advantage, while competition between the firms stimulated technical advance (see for instance, Becattini, 1990; Bellandi 2003). This unique interaction of co-operation and competition within districts was often associated with greater innovation (Lado et al., 1997).

A crucial element of such relationships is they are associative i.e. they involve a two-way, inter-change between actors (Cooke and Morgan, 1998). Molina Morales and MartinezFernandez (2006) refer to this in terms of the relational capital existing between firms, defined as the co-operative and trusting attitudes that aid collective learning processes (see also Capello, 1999). Their study of 5 Valencian industrial districts, for instance, found that constructs capturing the degree of relational capital among firms, were significantly correlated with firms' innovative performance. Morgan (2004) has also recently stressed the importance of physical proximity between firms in strengthening relational assets such as trust and co-operation for innovation, suggesting that face to face communication remains the main medium for enhancing (tacit) knowledge flows. Again, geographical proximity is likely 
to facilitate reciprocity, interaction and the nurturing of trust between firms, providing the foundations for a 'collective learning' environment from which new spin-off ideas and innovations can emerge.

Previous regional studies of inter-firm co-operative ties in the UK have found a positive relationship with innovation. De Propris (2000, 2002), for instance, explored co-operative ties among predominantly small and medium sized firms in the West Midlands manufacturing region. Using binary variables to capture co-operative ties between firms, she finds that firms engaging in co-operation with both client firms and suppliers are more likely to be product innovators, while those that co-operate closely with their suppliers are also likely to engage in process innovation. Freel and Harrison (2006) also uncovered similar results in a much larger regional survey exploring co-operative ties and innovation in small and medium sized manufacturing and service sector firms in Northern England and Scotland. Both studies highlight the importance of collaboration along the supply chain for innovation within a regional context, although whether such patterns are particularly germane to the region is indeterminate given both studies' sole focus upon geographically bounded firms. A further issue ignored in both studies is the actual strength of such co-operative ties in the innovation process $^{7}$. Tomlinson (2010), for instance, has recently argued that strong and close inter-firm ties are particularly conducive for improving firms' innovative performance. Within this context, it may be that because of the potential for greater reciprocity, geographically proximate firms are more likely to engage in and benefit from stronger co-operative ties (Morgan, 2004).

H2: Firms benefit from strong co-operative ties in terms of higher innovative performance. This is likely to be more pronounced for district vis-à-vis non-district based firms. 


\subsection{Institutional Support}

A final issue to consider is the role of institutions, which are often highlighted in the literature as having a positive impact upon the innovation process, particularly within industrial districts $^{8}$. Following Molina Morales and Martinez Fernandez (2004), institutions might be defined as encompassing a wide range of organisations including universities, industry specific research institutes, trade bodies and regional policy actors and which support the whole sector. These institutions can provide firms with a repository of knowledge, through the storing of databases and production of trade journals, while also offering training facilities and research laboratories; in turn this facilitates new knowledge creation and innovation.

Moreover, institutions may act as a conduit for external links with other firms and agents (such as new clients), providing new sources of knowledge and information flows. These links may, for instance, be nurtured through organising annual trade fairs or industry specific research conferences, both of which can bring (district) firms into fruitful liaisons with external actors (usually without (district) firms having to engage in costly searches for new partners) ${ }^{9}$. Such external links can, for instance, compensate district firms for overembeddedness, where the district and its constituent firms become too narrowly focused upon their own (particularly R\&D) activities (Laursen and Salter, 2006). Indeed, if district firms can successfully utilise external knowledge sources with their own resources - while also drawing upon the district's 'Marshallian' atmosphere - then this can again aid innovative performance (Hervas et al., 2008). It is argued that the aforementioned benefits derived from close links to institutions (and their activities) are particularly pronounced within territorial agglomerations of firms, such as industrial districts and, due to their relative isolation, nondistrict firms are unlikely to exploit and benefit from such collective resources (Molina Morales and Martinez Fernandez, 2004). 


\begin{abstract}
H3: Firms will benefit from close links to institutions in terms of higher innovative performance. This is likely to be more pronounced for district vis-à-vis non-district based firms.
\end{abstract}

\title{
3. The UK table and giftware sector
}

\subsection{Background}

The table and giftware sector consists of the manufacture of ceramic household and ornamental articles, including tableware, kitchen ware, ornamental and giftware. These products are manufactured in earthenware, bone china, stoneware, porcelain and vitreous china. With an annual output of $£ 268$ million in 2007 , the sector accounts for approximately a third of total output within the UK ceramics industry (Office of National Statistics, 2007). While the industry is predominantly small-scale in nature - with a large number of small independent producers - there are a few, larger and more prominent firms.

These larger firms are primarily based in and around Stoke-on-Trent, North Staffordshire, which is where the UK ceramics industry is mainly concentrated. The North Staffordshire area has deep historical roots and associations with the ceramics industry and is affectionately known as 'The Potteries' (see Whipp, 1990). This old 'industrial district' region has a long and proud international reputation in the design and manufacture of high quality ceramics, with prominent table and giftware firms (and famous brands) such as Wedgwood (established 1759), Minton (1793), Aynsley (1775) and Spode (1780) originating from the region. Today, the district accounts for approximately $32 \%$ of all UK ceramics firms (around 350 ceramics related businesses are believed to operate in the region) and $60 \%$ of total UK ceramics employment (Advantage West Midlands, 16/10/09). The district is also the base to a number of industry related institutions including The British Ceramic Confederation (BCC), The 
Association for Ceramic Training and Development (ACTD), The British Ceramic Plant and Machinery Manufacturer's Association, CERAM Research and the Ceramic Industry Forum (CIF). While some leading companies have and continue to operate outside the district (examples include Royal Crown Derby and Denby), these companies also retain close links with the district, primarily through the associated industry institutions and the supplier-base such as manufacturers of kilns, pottery plant and machinery (including pressings and mouldings) and clay, glaze and colour producers.

\subsection{Recent trends and global outsourcing}

Recent trading conditions within the sector have been difficult, with domestic sales of ceramic household and ornamental wares falling by 39.6\% between 2003 and 2006 (Keynote, 2008). UK firms have, in particular, been adversely affected by rising international competition (from predominantly low cost East Asian manufacturers) in both the domestic market and in their traditional export markets. Indeed, while the table and giftware sector has over a long period earned the UK a significant export surplus, its trade balance has been in continual deficit since 2004 (Keynote, 2008). The initial impact of this competition was upon the high volume, low value added end of the sector, although recently the more lucrative medium to upper end of the sector has been affected (see Day et al., 2000). The response of larger and medium sized tableware manufacturers has in recent years been to move their operations to East Asia and/or outsource production to East Asian producers.

Outsourcing within the industry and the district, in particular, is not new. Indeed, table and giftware firms have for a long time outsourced production within the district. While outsourcing can inhibit the growth of individual firms into wider activities, in general and from a resource based perspective it has provided table and giftware firms with greater flexibility in dealing with fluctuating demands in the industry, while allowing them to 
concentrate their own resources on their core activities. Historically, such horizontal collaboration between district firms has also facilitated inter-organisational learning and has allowed the district as a whole to retain its core competencies, while maintaining employment and critical mass (see Carroll et al., 2002). However, the recent outsourcing of production to the Far East is widely regarded has having a detrimental upon the UK industry with a number of high profile company insolvencies, factory closures and large scale redundancies occurring, particularly within the North Staffordshire district. Ceramics related employment within the district, for instance, has fallen from approximately 21,800 to around 7,200 in the decade to 2006 (see Sacchetti and Tomlinson, 2009). Such a dramatic fall in employment has an adverse effect upon the district's capabilities and in particular the skills-base, with displaced workers often being reluctant to remain in (or return to) the sector, given the uncertainty surrounding future employment prospects (Ceramic Innovations, 2003, p.16).

\subsection{Innovation within the district and the sector}

While previous UK based academic studies tend not to associate traditional sectors such as ceramics with innovation, it is the case that over the last forty years the UK ceramics industry has itself witnessed significant technical change. Some of the main innovations are documented by Warren et al., (2000). On the process side, they have included greater mechanisation to control and improve the consistency of raw materials, the introduction of single fire technology and new forms of organisation within the workplace. There have also been notable improvements to clays and glazes and in design techniques to enhance product development. These changes have been seen as delivering faster throughput times, raising efficiency and improving product quality in the industry.

In exploring the sources of innovation, Warren et al. (2000) emphasise the specific role played by the district based institutions, particularly CERAM research which provides 
consultancy, testing and technical support across the whole ceramics industry. The authors suggest that CERAM research has been instrumental in pulling together innovative ideas, promoting collaborative ties between firms and securing and managing external funding for research and development within the sector. We might also include here reference to the 'Hothouse Project', a largely publicly funded ceramic shape and pattern design centre located within the district and which is equipped with the latest 3D printing and prototype technology along with CAD and CAM tools. This centre of excellence aids firms in bringing new designs to markets more quickly, and serves firms across the whole sector, with firms being able to take advantage of the centre's facilities and expertise (for a set fee), without incurring the high sunk costs associated with investing in specific technologies (see Sacchetti and Tomlinson, 2009).

Both product and process innovations have enabled some district firms to thrive in what has been a turbulent period. Most notable are the hotel-ware companies, Churchill, Dudson and Steelite who have adopted a strategic approach based upon continual product innovation and critically developing close (long term) relations with their client base; building reputations for quality and reliability, particularly in the servicing of hotel-ware sets over the product life cycle $^{10}$. In the more general table and giftware markets, Emma Bridgewater, Portmeirion and Wade have also succeeded through competitive (and distinctive) designs and marketing, the latter strongly associating products manufactured within the district; the district's historic reputation for (quality) ceramics production being a unique selling point (see Sacchetti and Tomlinson, 2006). These companies are considered leading innovators within the district and they have invested significantly in new machinery to improve throughout times and reduce costs. Wade's recent investments in new pressure casting machinery, for instance, has brought production costs down to comparable levels in the Far East, while maintaining their own employment levels within the district (Staffordshire Sentinel, 26/10/10). Finally, the 
high quality giftware producer Moorcroft, which having been on the verge of bankruptcy in the mid-1980s, has also thrived producing solely in the district and focusing upon developing unique shapes and design patterns; their strategy here has been to place a particular emphasis upon the bespoke art of their designers, who produce highly collectable items.

Within policy quarters, the emphasis is upon continuous product and process innovation so as to retain a degree of competitiveness within the district, providing district firms with sources of added value. Innovations in product development (and creative designs) combined with effective marketing protects and enhances market share (and facilitates premium pricing of products), while more efficient processes reduce production costs; both are important for district firms in negating the negative impacts of globalisation. While the district's institutions play a role in supporting such activities (see Section 6), there has been a recent interest in fostering closer network ties and co-operation between firms and in developing external linkages to exploit new knowledge sources (see for instance, North Staffordshire Taskforce (2003, Section 2.9) and SQW Consulting, 2009)).

\section{Research methodology}

While the primary focus of our research is to measure the impact of collaboration upon innovation within the North Staffordshire district, it is also important to assess whether any such correlation(s) are unique to the district or are applicable to the industry more widely. The research therefore drew upon a sample of table and giftware producers, both from within the North Staffordshire district and also across the UK. A mixed methodological approach was employed, using a combination of interviews and questionnaires to gather data and valuable insights about the sector. 
At the onset of our research in the Spring of 2008, a small number of interviews were conducted with managing directors of table and giftware firms located within the North Staffordshire district. These interviewees were approached through our own personal contacts within the industry, although care was taken to ensure they were representative of table and giftware firms within the district (in terms of size and product scope). An unstructured interview approach was taken, and the interviewees provided us with some useful background information about industry issues - in particular about co-operation and the nature of innovation within the sector - and this guided the construction of the questionnaire. Following the questionnaire and the statistical analysis of the data (see Section 5), further interviews were conducted with 15 firms within the district and who had indicated (on the questionnaire) a willingness to participate further in our research. These interviews explored a number of issues relating to the development and future of the district and the industry, and also focused upon interpreting and discussing the implications of our empirical results (see below).

The postal questionnaire was distributed to the Managing Directors of 331 ceramics firms in the UK table and giftware sector in September 2008. The sample frame was drawn from The Ceramics Industry Forum's membership directory and supplemented with smaller independent table and giftware producers listed on Yell.com, using a random stratified sampling process to select firms. These were selected in proportion to the size distribution of firms within the sector, as recorded by the Office for National Statistics (see Appendix: Table A1) [4]. In total, 128 district and 203 non-district firms were contacted and in order to induce a higher response rate, a $£ 1$ donation was promised to a recognised charity for each completed and returned questionnaire received. A reminder was sent out three weeks after the initial mail-out and the final reminder was mailed two weeks later. The questionnaire included questions on the firm's business background, firm size and revenues, their R\&D and 
innovation activities as well as their co-operative and network ties. The innovation and cooperation questions covered a range of activities and the responses were measured using a structured set of Likert scales (see Table 1). In total, there were 118 valid responses from UK table and giftware producers (a $35.6 \%$ response rate), with responses from 54 (42\%) district and $64(31.5 \%)$ non-district firms. This gave a sampling error of $5.4 \%$ at the $95 \%$ confidence interval, which is within the acceptable limits for survey research (see Oerlemans et Al., 2006). Finally, the sample was a fairly close reflection of the size distribution of the population of firms in the sector (for further details, see Appendix: Table A1).

\section{Model Specification and Variable Construction}

\subsection{Model Specification}

In line with other studies, we employed a standard innovation production function, which was supplemented with appropriate independent predictors (see Geroski, 1990, De Propris, 2002, Freel and Harrison, 2006, Molina-Morales and Martinez-Fernandez, 2006):

Innovation $=\beta_{0}+\beta_{1}$ Firm Size $+\beta_{2} \mathrm{R} \& \mathrm{D}+\beta_{3}$ District Affiliation $+\beta_{4}$ Vertical Co-operation + $\beta_{5}$ Horizontal Co-operation $+\beta_{6}$ Institutional Support $+\beta_{7}$ Vertical Co-operation $x$ District Affiliation $+\beta_{8}$ Horizontal Co-operation $x$ District Affiliation $+\beta_{9}$ Institutional Support $x$ District Affiliation (1)

In short, the model includes a set of internal (control) variables, a dummy variable to capture the district effect and augmented with constructs to measure the impact of external sources, namely measures of vertical and horizontal co-operation and institutional support. Multiplicative dummies to assess the impact of co-operative ties specifically within the North 


\subsection{Independent Variables:}

\subsubsection{District Affiliation}

Following, Signorini (1994), a dummy variable was used to account for firms whose main location was based (within a 30 mile radius) in the North Staffordshire industrial district, which is the main agglomeration of table and giftware firms in the UK 11. The dummy variable captures the impact of being located within the district and agglomeration effects upon levels of innovation. Firms located outside the district do not enjoy these agglomeration economies. In line with the literature on industrial districts and, in particular in relation to learning regions and innovative milieu, it is expected that being located within the district has a positive impact upon levels of innovation.

\subsubsection{Co-operation variables: Vertical and Horizontal Co-operation}


Unlike previous studies which use a simple binary variable to indicate whether co-operation between firms occurs or not, we measure co-operation in its wider context across a range of activities and employ a 5 point Likert scale, where $1=$ No co-operation to $5=$ Very high level of co-operation. Such an approach has the advantage of allowing us to capture more information on the nature and scale of co-operative relations between firms. Respondents were asked the extent to which their firm engaged in co-operation with their $i$ ). main buyer/client firms ii). main supplier firms and iii). main competitor firms using the items listed in Table (1) and which are based upon a set of studies into co-operative behaviour between firms by Schmitz, H (1999, 2000), Knorringa (1999) and Nadvi (1999).

1. Vertical Co-operation: Initial experimentation appeared to reveal a degree of multicollinearity between both buyer and supplier co-operation. In order to overcome this, both these constructs were therefore amalgamated into a Vertical co-operation construct, again using principal components analysis. Following the earlier discussion in Section (2), it is expected that higher levels of co-operation along the value chain will be positively associated with levels of innovation.

2. Horizontal Co-operation: Following the literature on industrial districts, innovative milieu and learning networks (see Section (2)), it might be anticipated that higher levels of horizontal co-operation lead to higher levels of innovation (both product and process) in the firm. The counter possibility is a negative relationship between horizontal co-operation and the level of recorded innovation, since (horizontal) alliances can lead to the avoidance of waste and duplication of effort (see Hitt et al. (1997)). A further issue here, and particularly pertinent given our earlier observations (see Section 3.2) about recent trends in the table and giftware sector, is the impact of horizontal collaboration with Far Eastern producers upon the innovative capability of district firms (see Carroll et al. 2002). 


\subsubsection{Institutional Support}

This construct attempts to capture the impact of external support provided by the ceramics industry institutions and also academic related institutions upon innovation. As already noted, the majority of these institutions are based within the North Staffordshire district, although their industry links are much wider. The items are listed in Table (1) and are guided by the roles such institutions play within industrial and regional development (Maillat 1995, Helmsing, 2001, Molina Morales and Martinez-Fernandez, 2004). In line with H3, it is posited that such institutions have a positive impact upon the level of innovation, particularly in relation to district firms.

For all constructs, the mean of all the relevant items for each firm was calculated, with Cronbach's alpha again being run to validate the aggregation process.

\subsubsection{Control variables}

Previous studies have suggested that internal resources are positively related to firm innovation (see, for instance, Cohen and Levinthal, 1990, Symeonidis, 1996, Freel, 2003) and so in order to control for this, the model also included measures of Firm size and Research and Development (R\&D) expenditure. Table (1) provides details of the construction of these control variables. In line with previous studies, both variables are segmented into categorical scales, with Firm Size measured in terms of the number of employees and R\&D expenditure expressed as a proportion of sales turnover. Both variables are expected to be positively associated with firm innovation.

\section{INSERT TABLE (1) HERE}

\subsubsection{Descriptive Statistics}


Table (2) provides details of the descriptive statistics. The bivariate correlations indicate significant correlation between some of the independent co-operation variables. However, while sensitivity between independent variables can give rise to estimation problems, the reported (low) variance inflation factors suggest that multi-collinearity (in the sample) was not a problem. For the construct variables, Cronbach's alpha $(\alpha)$ is also reported. This is important in assessing convergent validity i.e. whether the items used in specific constructs are related (or share a high proportion of variance in common). In all cases, Cronbach's alpha was greater than the accepted minimum level of 0.70 , thus satisfying the criteria for internal consistency and reliability (Hair et al., 2007). Tests for discriminant validity were also conducted by comparing the variance-extracted estimates for pairs of constructs with the square of their respective correlation coefficient (see Hair et al, 2007). This captures the extent to which a construct is unique and captures phenomena other measures do not i.e. that it is distinct (Campbell and Fiske, 1959). The test statistics supported the hypothesis that discriminant validity was present [5]. Finally, face validity - the theoretical justification for using particular scale items - was satisfied by utilising previous used multi-scale items and being guided by the literature on innovation, co-operation and industrial districts. Following these tests, the factor scores for each construct were calculated in SPSS, each with a standardized mean of 0 and a standard deviation of 1 , and in accordance with Hair et al (2007) these were used in the ensuing regression analysis.

\section{INSERT TABLE (2) HERE}

\subsection{Results and Discussion}

\subsection{Regression Results}

Estimation of equation (1) followed Molina-Morales and Martinez-Fernandez (2006) and took the form of a hierarchical regression model. First innovation was regressed on the 
control variables, with the predictor variables being subsequently added and finally the multiplicative dummy variables being included. The regression results are presented in Table (3). The first point to note is that the model appears a reasonable predictor of the level of innovation within the sector. The adjusted $\mathrm{R}^{2}$ statistics are relatively high in comparison to previous studies and generally improve with the addition of the predictor variables, while the reported Akaike information criterion falls with the addition of such variables. This would suggest that the augmented models are preferred.

\section{INSERT TABLE (3) HERE}

As expected, both Firm size and R\&D expenditure are positive and highly significant in models (1) through to (7), thus indicating the importance of internal resources for raising the level of innovation within the sector. The positive and significant impact of the dummy variable for district affiliation in models (1) to (5), indicates that firms located within the North Staffordshire district benefit from their close proximity, the 'Marshallian atmosphere' and the intrinsic advantages associated with industrial agglomeration (see Section 2). Thus H1 is supported, suggesting that old traditional districts (and industries) can act as conduits for industrial change and innovation (Warren et al., 2000).

There are some clues in identifying the district's intrinsic advantages in regressions (2) to (7), where there is some partial support for H2. First, the introduction of vertical co-operation appears to have, albeit at $10 \%$, a positive and significant impact upon innovation across the whole sector (models (2) and (3)). This is perhaps not surprising given that the influence of the value chain in promoting innovative activity has been widely documented (Tether, 2002). The introduction of horizontal co-operation though does not appear to have any significant impact across the whole sample (models (4) to (7)). What is particularly interesting however, is that when these co-operation constructs are applied only to district firms (through multiplicative dummies), both vertical and horizontal ties appear to have a highly significant 
impact (models (5), (6) and (7)); although in the latter case the effect appears to be negative. The dummy variable capturing district membership also becomes insignificant, implying that the impact of inter-firm collaboration for innovation is particularly germane for district based firms. An additional salient point is the multi-scalar and multi-dimensional approach in relation to measuring the variables of interest suggests the nature and intensity of the dyad between partner firms is an important consideration; in short where district firms engage higher levels of co-operation with their partners over a range of activities, this has a significant impact upon levels of innovation ${ }^{12}$.

The initial conclusion here is that district firms engaging in strong vertical ties - across a range of activities - benefit in terms of innovative performance. In this respect, upstream cooperation with suppliers over the uses of different clays and glazes and downstream cooperation with buyers/retailers (for instance, at trade fairs) over new designs can often enhance levels of product improvement. Similarly, co-operation over delivery times, technology, labour training (e.g. through the ACTD) and production organisation along the value chain also play an important role in generating positive feedback effects and synergies between firms and raising levels of process innovation. Turning towards horizontal cooperation however, there appears to have a (significant) negative impact on the district firms' levels of innovation. One likely interpretation is that through combining resources, cooperating firms are avoiding duplication in their (joint) innovative activities, which is reflected in a lower level of recorded innovation (see Hitt et al. (1997)). There is however an alternative explanation. As mentioned earlier, district firms have increasingly been collaborating with Far Eastern partners in relation to global outsourcing (for instance in China and Indonesia). In the medium to longer term, the impact may reduce their own capabilities and competencies, thus adversely affecting their innovative potential and this is 
captured by the significantly, negative coefficient. Unfortunately, our sample does not distinguish between whether such ties occur within/outside the district and/or external partners beyond the UK. However, given our earlier observations on global outsourcing, this inference is certainly plausible and is a live issue. We return to this in Section (6.2).

Finally, turning to the role of institutional support, H3 is also partially supported. In models (3) to (7), the results reveal that firms across the whole sector appear to benefit positively in terms of innovative performance from receiving external support for R\&D related activities provided by industry and academic related institutions. As noted in Section (3.1) the UK ceramics industry has a recognised and established group of supporting institutions that actively play a role in assisting firms with regards to innovation in the sector and their impact appears to have been captured in our sample. However, while these institutions are predominantly based within the North Staffordshire district, there is no evidence (from the sample) to suggest that the benefits accrue solely to district firms (Column 7). While this result is perhaps surprising given the (relative) importance of geographical proximity, it does not imply that district firms do not benefit from close links with institutions; rather the industry's institutions are now also more widely linked with non-district based UK firms who derive similar benefits. Interestingly, this can potentially enhance both the district and wider industry's innovative capacity, as the institutions act as conduits for nurturing inter-firm links and sources of new knowledge (see Section 2 and 6.2).

\subsection{Further Discussion and Insights from Interviews}

As already noted, the survey data only provides partial information on the extent of inter-firm collaboration, but does not distinguish between ties within or outside the district. The interview data is therefore particularly useful in helping us to unravel the nature of inter-firm 
ties in relation to district firms, and aid us in exploring further their impact upon innovation within the district.

In terms of vertical co-operation, the strength of the industry's supply chain has long been documented in regional and industry quarters (see North Staffordshire Taskforce Report, 2003; SQW, 2009) and both formal and informal types of (vertical) co-operation appear to exist within the district. For the smaller micro-firms, informal vertical co-operation generally takes the form of technical advice and guidance provided by local suppliers for example on the consistency of clay, types of glazes or appropriate firing temperatures. This source of advice can be invaluable where the firm is not sufficiently large enough to employ specialists in all aspects of production. In general, there tends to be a rapport between the smaller manufacturing firms and the clay, glaze, colour and other material suppliers as each recognizes their mutual interdependence. Being co-located in the same district also facilitates a close network of contacts through which technical issues can be solved jointly or through the previous experience of a related or similar firm (the district effect). Tacit know-how is an important feature of the district (and industry) at this level, especially where firms communicate verbally rather than through technical peer-reviewed academic papers as in other industries such as bio-technology.

For larger firms, there is evidence of more formal vertical co-operation often placed in a legal framework or via working agreements. These tend to range from premium-priced tableware manufacturers having exclusive product design deals with key retail outlets; to glaze suppliers committed to continuous process innovation with the main manufacturers within the district. In both cases, this outcome is a response to the on-going pressures of cost reductions generated by globalisation and low-cost foreign imports. In the former case, the ceramics manufacturer can reduce its own price elasticity of demand through adding value in the branding and design of surface patterns and/or ceramic body shapes; and in the latter case the 
supplier can offer environmental benefits and cost reductions by firing at lower temperatures through innovation work jointly with the pottery manufacturer. Both firms acknowledge the respective products are operating in niche markets but consider this approach the best way to add value at the various stages of the supply chain.

Turning to horizontal co-operation there are fewer and much less obvious examples on a firm-to-firm basis within the district. From our original sample, just under a third $(29.7 \%)$ of all district firms engaged in horizontal co-operation within the district (see Table (4)). In essence, firms in the table and giftware sector have tended to view one another as 'fellow travellers' and do not collude with one another in an anti-competitive manner. While (horizontal) outsourcing has and still occurs within the district (see Carroll et.al, 2002), much of the horizontal innovation between district firms now tends to be through the industry's institutions such as the British Ceramics Confederation (BCC) and CERAM Research. Such co-operation can involve the joint promotion of the industry, through industry fairs organised within the district and also through mutual research collaborations (see also Warren et.al 2000). There are however, a couple of examples of horizontal co-operation that are indicative of the nature of collaboration that occurs within the district. In this regard, Furlong Mills Limited is a jointly owned operation, whose main shareholders include the major (district based) tableware manufacturers, Dudson (Holdings) Limited, Portmeirion and Churchill China. Furlong Mills is a leading supplier of processed material to the ceramics industry with a product range that includes silica, feldspar and composite ceramic fluxes processed to the bespoke requirements of the customer. The company is based in Burslem, in the north of the district, and it has facilities for crushing, grinding, blending and drying material as well as being accessed by a customer base beyond the three main shareholders. The operation benefits the three main shareholders in two main ways. Firstly, the shareholding firms have local access to the process and product innovations of a leading ceramics material supplier 
(generating economies of agglomeration); and secondly, because the set-up has a wider customer-base than the three main shareholders then there is the potential for greater utilization of the plant and machinery within the district (facilitating economies of scale).

Occasionally district firms specifically pool resources to jointly develop new technology and processes: such arrangements are typically referred to as 'buddying' within the district. In this respect, a relatively recent (and particularly noteworthy) example of 'buddying', which also involved collaboration with industry suppliers and was facilitated through CERAM Research, has been the development of new pressure casting machinery and techniques for the table and giftware sector. Pressure casting is designed to reduce the problems of air compression in the mould and casting process. While the technique has been used in industrial ceramics, similar techniques have been difficult to employ in the table and giftware sector where more complex and variable multi-part moulds are required. Collaboration here has led to the development of more durable synthetic and porous moulds and a reduction in casting times, thus improving production efficiency. The new techniques (originating from within the district) are regarded as setting a new world standard, which allow for greater flexibility in production runs while the new moulds themselves have a finer, tightly controlled pore structure that improves ware surface quality.

As we have already noted, one particular issue of contention in recent years has been the impact of increasing horizontal ties with firms from outside the district, in particular outsourcing arrangements with Far Eastern producers. This could be detrimental to innovative activity within the district, particularly when skills and competencies (particularly those relating to displaced workers) are transferred to the Far East (see also Ceramic Innovations, 2003). While only $18.5 \%$ of all district firms in our sample engage in international co-operation, it is notable that such activities are predominantly undertaken by the larger manufacturers $(55.5 \%)$, who are also (by definition) the largest employers (see 
Table (4)). Such firms have announced a number of large scale redundancies in recent years as their production plans have shifted to the Far East and this can create an air of despondency and inevitability within the district, particularly with regard to employment prospects (see Sacchetti and Tomlinson, 2009). Our interviewees revealed concerns that as result of global outsourcing by larger manufacturers, the district was now suffering a skills shortage particularly with regards to gilders, dish-makers, lithographers, spongers and semiautomotive holloware operators. Indirectly, the loss of such skills can have adverse impact upon innovative capacity within the district, as firms become less able to access/utilise employees with traditional crafts. It is possible that the negative co-efficient on the horizontal co-operation variable in Table (3) may be capturing some of these effects.

\section{INSERT TABLE (4) HERE}

Finally, our interviews also broached the role of institutions in the table and giftware sector. The regression results (Table 3) indicate that close ties with institutions are likely to enhance innovative activity, though this impact is across the whole sector and not confined solely to district firms. We have already mentioned the types of institutions that exist within the district (see Section 3.1) and provided some discussion, but it is worth briefly providing some further detail on the nature of their main roles in facilitating innovative activity.

In particular, our interviewees acknowledged the role served by CERAM Research, which was established in 1920 and is now a global leader in materials analysis including research, development and quality testing aimed at improving the manufacturing yield of ceramics materials. One of the most effective examples of institutional co-operation on innovation is the network of organizations known as Powdermatrix, which was initiated and is managed by CERAM. Powdermatrix is a knowledge transfer network consisting of over 200 firms, research institutions and organizations involved in particulate engineering. The key strength 
of the network is that although it focuses primarily upon advanced ceramics, powder metal, hard metal and magnetics industries it has been able to attract other sectors such as pharmaceuticals and food. This allows the participating firms to gain access to almost every expert in materials technology and thereby gain valuable institutional support in developing new product and process innovations. Interestingly, the actors involved are based both within and outside the district; this network is not geographically confined. CERAM's role here demonstrates its wider focus in facilitating industry development beyond the district's boundaries.

Similarly, BCC represent the whole ceramics industry and collaborate with actors both inside and outside the district across areas of innovation, such as chemical compliance and emissions reduction to tie-in with central government policy on environmental management. In addition, the Ceramics Industry Forum (CIF) launched in 2000 as a non-profit organization to helps firms across the whole ceramics industry with process improvement, design, marketing and human resources; this has helped to create best practice across the sector in many areas of cost reduction and strategic planning in line with policy aimed at developing the skills and knowledge base of UK manufacturing. In short, in recent years the industry's institutions appear to have developed wider links beyond the district's boundaries; this seems to benefit the industry as whole, as the institutions collate and facilitate an exchange of knowledge and experiences across the whole sector. There is an obvious analogy here with the literature on exploiting knowledge flows through 'global pipelines' and combining it with the 'local buzz' (and vibrancy) that exists within the district (for further details on this subject, see Storper and Venables, 2004, Wolfe \& Gertlet, 2004). 


\subsection{Concluding Comments}

In recent years, the UK ceramics industry has been the focus of various policy directives to foster greater inter-firm networking. Such directives are often seen as enabling firms to raise their performance particularly in the area of innovation, where firms can benefit from the exchange of information and resources, inter-organisational learning and synergies in production (see Huggins, 2001, Bailey and De Propris, 2009a and b). This is particularly pertinent for old industrial districts, such as North Staffordshire, whose table and giftware sector has struggled to cope with rising international competition. However, the evidence on the extent to which this is occurring and the derived benefits for the North Staffordshire district is mixed.

Using survey data and drawing insights from a series of interviews, we explored the impact of external sources upon innovation in the UK table and giftware sector. We found that to some extent, locational economies are still important in this old, traditional industry for innovation. Generally, the 'district effect' has a positive impact upon innovation, suggesting the 'Marshallian atmosphere' remains alive within the North Staffordshire district. The main source of these district advantages appear to relate to close and strong co-operative ties existing along the value chain. To further improve this dyad (and to maintain competitive advantage), recent work on the socialisation of the value chain might be worth exploring. This might include considering new initiatives such as developing more open communication systems along the chain; facilitating greater reciprocity in discussion and joint problem solving to build relational capital and enhance long term relationships (see Cousins et.al 2006). 
The remaining district advantages are, however, less clear cut. For instance, while geographical proximity facilitates horizontal collaboration within the district, such ties are generally less noticeable and occur on an ad-hoc basis. They are not a systemic feature of the district. In contrast, in recent years the larger district firms have sought to establish horizontal linkages with partners in the Far East. While such external links potentially open up new opportunities (and knowledge flows), there have been justifiable concerns that such practices are based upon East Asia as being a low cost source of production and the flow of knowledge and expertise has largely been one-way; a transfer of jobs and skills, and innovative capacity away from the North Staffordshire district.

Developing external links, however, is critical in ensuring the district is able to access new knowledge sources and industrial techniques. In this regard, there is a role for the industry's institutions, which play a significant role in ceramics innovation specifically in terms of facilitating network links between firms and providing specialist research facilities. That these institutions are located within the district means it retains a significant degree of innovative capability; both CERAM and The Hothouse are internationally acclaimed centres of excellence ${ }^{13}$. The location of such institutions is a product of the historic industrial agglomeration of ceramics production within the district and close proximity facilitates easy access for district firms to collective services; potentially these can be utilised by district firms to diversify and upgrade their products. Yet, despite their location, the results suggest the benefits such institutions provide are not solely accrued by district based firms. While this, may be indicative of the declining importance of being located within the district for receiving such support, it demonstrates institutions being more widely connected and open to external sources that in turn, benefit the whole industry and the district, opening up the possibility of exploiting knowledge flows from outside the district's boundaries. 
In summary, the future for the table and giftware sector and the district, in particular, lies in producing (relatively) low volume but (definitely) high quality ceramic products. The district retains some systemic advantages, and will need to focus more closely on these in the future. Innovations and the related creative output coupled with a long-standing reputation for excellence is likely to be the way forward for ceramics firms in the district both individually and collectively.

\section{Acknowledgements}

We are grateful for the comments and suggestions of two anonymous referees. An early version of this paper was presented at the Regional Studies Conference, held in Pecs, $24^{\text {th }}-$ $26^{\text {th }}$ May 2010. 


\section{References}

Advantage West Midlands (16/10/09) Stoke-on-Trent, the World Capital of Ceramics http://www.advantagewm.co.uk/news-media-events/news/2009/10/stoke-on-trent-the-worldcapital-of-ceramics.aspx

Ahuja, G. (2000) 'Collaboration Networks, Structural Holes and Innovation: A Longitudinal study', Administrative Science Quarterly, 45, 425-455

Bailey, D \& De Propris, L. (2009a) Industrial and Regional Policies in an Enlarging EU London: Routledge.

Bailey, D and De Propris, L. (2009b). 'Towards a Knowledge-Intensive, Green Manufacturing Future', in R. Hornsey, S. Howarth, P. Morton, O. Nicholls and R. Paskins, ed.s, West Midlands: Fit for the Future? Positioning the Economy for Economic Recovery. Birmingham: West Midlands Regional Observatory.

Becattini, G (1990). The Marshallian industrial district as a socioeconomic notion, in F.Pyke, G.Beccatini, and W.Sengenberger (eds), Industrial Districts and Inter-firm Co-operation, pp.37-51, Geneva: International Institute for Labour Studies,.

Bellandi, M.(2003). Industrial Clusters and districts in the new economy: some perspectives and cases in R.Sugden, R.H.Cheung and G.R Meadows (Eds) Urban and Regional Prosperity in a Globalised New Economy, pp. 196-219. Cheltenham: Edward Elgar.

Boekema, F, Morgan, K, Bakkers, S \& Rutten, R (2000), Knowledge, Innovation and Economic Growth: The Theory and Practice of Learning Regions (Cheltenham, Edward Elgar).

Boschima, R.A. \& Ter Wal, A.L.J (2007) 'Knowledge Networks and Innovative Performance in an Industrial District: The Case of a Footwear District in the South of Italy', Industry and Innovation, Vol. 14, no.2, 177-199 
Bougrain, F \& Haudeville, B (2002) 'Innovation, Collaboration and SMEs internal research capacities', Research Policy, 31, 735-747.

Camagni, R. (1991) 'Local 'milieu', uncertainty and innovation networks: towards a new dynamic theory of economic space', in R.Camagni (ed) Innovation Networks: Spatial Perspectives, pp.121-142. London: Belhaven.

Campbell, D.T. \& Fiske, D.W. (1959) 'Convergent and Discriminant Validation by Multitrait Multimethod Matrix’, Psychological Bulletin, 56: 81-105

Capello, R. (1999) 'Spatial transfer of knowledge in high-technology mileux; learning versus collective learning processes', Regional Studies, 33, 4: 353-368

Carroll, M., Cooke, F.L., Hassard, J. and Marchington, M. (2002), The Strategic Management of Outsourcing in the UK ceramic tableware industry, Competition and Change, 6:4, 327-343

Ceramic Innovations (2003). Sector Workforce Development Plan. http://www.actd.co.uk/CINN/workfporce.htm

Cohen, W.S, and Levinthal, D (1990) 'Absorptive capacity: a new perspective on learning and innovation', Administrative Science Quarterly, 35,pp. 128-152.

Cooke, P. \& Morgan, K. (1994) 'Growth Regions Under Duress: renewal Strategies in Baden-Wuttemberg and Emilia-Romagna', in A.Amin \& N.Thrift (eds), Globalisation, Institutions and Regional Development in Europe (OUP: Oxford), pp.91-117

Cooke, P. Gomez Uranga, M. \& Etxebarria, G. (1997) regional Innovation Systems: Institutional and Organisational Dimensions, Research Policy, 26, 475-491.

Cooke, P \& Morgan, K (1998). The Associational Economy: Firms, Regions and Innovation. Oxford University Press. 
Cousins, P., Handfield, R.B., Lawson, B., Petersen, K.J. (2006) 'Creating supply chain relational capital: The impact of formal and informal socialization processes', Journal of Operations Management, Vol.24(6), 851-863

Day, M, Burnett, J, Forrester, P.L. \& Hassard, J (2000). 'Britain's last industrial district? A Case Study of Ceramics Production'. International Journal of Production Economics, 65, pp. $5-15$

De Propis, L (2000) 'Innovation and Inter-Firm Co-operation: The Case of the West Midlands', Economics of Innovation and New Technology, 9, 421-446

De Propis, L (2002) 'Types of innovation and inter-firm co-operation', Entrepreneurship and Regional Development, 14, 337-353

Dyer, J.H \& Singh, J.H. (1998) 'The relational view: co-operative strategy and sources of inter-organisational competitive advantage', Academy of Management Review, Vol.23, No.4, 660-679.

Foray, D. (1993) 'Feasibility of a single regime of intellectual property rights', in M.Humbert (ed). The Impact of globalisation on Europe's firms and regions, pp.85-95. London: Pinter.

Freel, M. (2003) Sectoral patterns of small firm innovation, networking and proximity, Research Policy, 32, 751-770

Freel, M.S \& Harrison, R, T (2006) 'Innovation and Cooperation in the Small Firm Sector: Evidence from Northern Britain', Regional Studies, 40, 289-305

Gay, P.W. \& Smyth, R.L (1974) The British Pottery Industry, London: Butterworths.

Gerlach, M.L. (1992) Alliance Capitalism: The Social Organisation of Japanese Business. (Berkeley: University of California Press).

Geroski, P. (1990). Innovation, technological opportunity, and market structure', Oxford Economic Papers, 42, 586-602. 
Hervas-Oliver, J. L. and Albors-Garrigos, J.\& Damau, J.L. (2008): External and the reduction of knowledge asymmetries among clusters within global value chains: case of the ceramic the district of Castellon. European Planning Studies, 16(4): 507-520.

Hervas-Oliver, J. L. and Albors-Garrigos, J. (2009) "The role of the firm's internal and relational capabilities in clusters: when distance and embeddedness are not enough to explain innovation" Journal of Economic Geography, 9, 263-283.

Hudson, R. (1999) 'The Learning Economy, The Learning Firm and The Learning Region: A Sympathetic Critique of the Limits of Learning', European Urban and Regional Studies, 6 (1), 59-72.

Huggins, R (2001) 'Inter-firm network policies and firm performance: evaluating the impact of initiatives in the United Kingdom', Research Policy, 30, 443-458

Inkpen, A.C. \& Tsang, E.W.K. (2005) 'Social Capital, networks and knowledge transfer'. Academy of Management Review, 30, 146-166

Jaffe, A. \& Trajtenberg, M. (1999) 'International knowledge flows: Evidence from patent citations', Economics of Innovation and New Technology, 8 (1-2), p.105-136. 
Jaffe, A., Trajtenberg, M. \& Henderson, R. (1993) 'Geographic localisation of knowledge spillovers as evidenced by patent citations', Quarterly Journal of Economics, 108 (3), pp.577-598.

Kaplinsky, R \& Readman, J (2001) Integrating SMEs in global value chains: toward partnership for development. Vienna, UNIDO

Keynote (2008) China and Earthenware Market Report (London: Keynote Market Reports)

Knorringa, P (1999) 'Agra: An Old Cluster Facing the New Competition', World Development, Vol 27, No.9, pp.1587-1604

Lado, A.A, Boyd, N.G \& Hanlon, S.C. (1997) 'Competition, co-operation and the search for economic rents: a syncretic model' Academy of Management Review, 22(1), 110-141.

Laursen, K \& Salter, A. (2006) 'Open for innovation: The role of openness in explaining innovation performance among UK manufacturing firms', Strategic Management Journal, $27 ; 131-150$.

Lundvall, B.A. (ed) (1992) National Systems of Innovation: Towards a Theory of Innovation and Interactive Learning, pp.23-44. London: Pinter.

Lundvall, B.A. \& Johnson, B. (1994) 'The learning economy', Journal of Industry Studies 1 (2): $23-42$.

Lundvall, B (1995) National Systems of Innovation: Towards a Theory of Innovation and Iterative Learning, Pinter: London

Maillat, D (1995) Territorial Dynamic, Innovative Milieus and Regional Policy, Entrepreneurship and Regional Development, 7:157-165.

Molina-Morales F.X. \& Teresa Martinez-Fernandez, M (2006) Industrial Districts: something more than a neighbourhood, Entrepreneurship and Regional Development, 18 (Nov), 503524 
Nadvi, K (1999). 'Collective Efficiency and Collective Failure: The Response of the Sailkot Surgical Instrument Cluster to Global Quality Pressures', World Development, Vol 27, No. 9, pp.1605-1626

North Staffordshire TaskForce (2003) Report of the North Staffordshire Taskforce http://www.advantagewm.co.uk/task-force-report.doc, Birmingham: Advantage West Midlands, West Midlands Regional Development Agency

Oerlemans, L.A.G., Buys, A.J., \& Pretorius, T. (2006). Research design for the South African Innovation Survey 2001. In W. Blankley, M. Scerri, N. Molotja, \& I. Saloojee (Eds.), Measuring innovation in OECD and non-OECD countries (pp. 227-250). Cape Town: Human Sciences Research Council Press

Office of National Statistics (2007) Ceramic Household and Ornamental Articles, Product Sales and Trade, PRA 26210 London: ONS

Pyke, F \& Sengenberger, W (1992) 'Introduction'; in Industrial Districts and Local Economic Regeneration. Eds Pyke F and W. Sengengerger, Geneva, ILO, pp.3-29 
Rowley, C. (1988). 'The illusion of flexible specialisation: the case of the domesticware sector of the British ceramics industry', New Technology, Work and Employment, 9:2, 127139

Sacchetti, S (2004) "Knowledge Caps in Industrial Development", New Political Economy, Vol. 9, No. 3, pp. 389-412

Sacchetti, S and Sugden, R. (2009, forthcoming) 'The Organization of Production and its Publics: Mental Proximity, Markets and Hierarchies', Review of Social Economy.

Sacchetti, S. and Tomlinson, P.R. (2006) 'Globalisation, Governance and Clusters: North Staffordshire ceramic and Prato Textile industries, in C.Pitelis, R.Sugden \& J.R. Wilson (eds) Clusters and Globalisation: The Development of Urban and Regional Economies, Edward Elgar, p.232-258

Sacchetti, S \& Tomlinson, P.R. (2009) 'Economic governance and the evolution of industrial districts under globalisation: the case of two mature European industrial districts', European Planning Studies, Vol 17, No.12, pp.1837-1859.

Sako, M., (1994) 'Supplier relationships and innovation'. In: Dodgson, M. Rothwell, R (Eds.), The Handbook of Innovation. Edward Elgar, Cheltenham, UK. pp. 268 - 274

Sammarra, A \& Biggiero, L. (2008) 'Heterogeneity and Specificity of Inter-Firm Knowledge Flows in Innovation Networks', Journal of Management Studies, Vol. 45: 800-829.

Shan, W., Walker, G. \& Kogut, B. (1994) 'Interfirm Cooperation and Start Up Innovation in the Biotechnology Industry', Strategic Management Journal, Vol. 15, 387-394.

Signorini, L.F. (1994) 'The price of Prato, or measuring the industrial district effect', Papers in Regional Science, 73(4), 369-392

Smitka, M. J. (1991), Competitive Ties: Subcontracting in the Japanese Automotive Industry (New York: Columbia University). 
Schmitz, H (1999) 'Global Competition and Local Co-operation: Success and Failure in the Sinos Valley, Brazil', World Development, Vol 27, No.9, pp.1627-1650.

Schmitz, H (2000) 'Does Local Co-operation matter? Evidence from Industrial Clusters in South Asia and Latin America', Oxford Development Studies, Vol 28, No, 3, 323-336.

Spender, J.C. (1996) 'Making Knowledge the basis of a dynamic theory of the firm'. Strategic Management Journal, 17; 45-62.

Storper, M. \& Venables, A.J. (2004) 'Buzz: the economic force of the city', Journal of Economic Geography Vol 4, no.4, 351-370

Symeonidas, G (1996) 'Innovation, Firm Size and Market Structure', OECD Economic Studies, No.27, pp.36-70.

SQW Consulting (2009) Growing the Ceramic Cluster in North Staffordshire:

Recommendations, (Cambridge: SQW Consulting)

The Staffordshire Sentinel (26/10/10) 'Pottery’s £3m robot helps cut costs and create jobs', Sentinel Newspapers, Etruria; Stoke on Trent.

Tether, B.S. (2002) 'Who co-operates for innovation, and why. An empirical analysis', Research Policy, 31, 947-967

Tsai, W and Ghoshal, S (1998) 'Social Capital and Value Creation: the role of intra-firm networks', Academy of Management Journal, 41: 464-478.

Von Hippel, E. (1976) 'The dominant role of the user in the scientific instruments innovation process', Research Policy, 5, 212-239

Von Hippel, E. (1988) The Sources of Innovations. Oxford: Oxford University Press 
Warren, M.P. Forrester, P.L., Hassard, J.S. \& Cotton, J.W. (2000). 'Technological innovation antecedents in the UK ceramics industry', International Journal of Production Economics, 65, pp.85-98.

Whipp, R (1990). Patterns of Labour. Work and Social Change in the Pottery Industry. (Routledge: London \& New York).

Wolfe, D.A \& Gertlet, M.S (2004) 'Clusters from the Inside and Out: Local Dynamics and Global Linkages', Urban Studies, Vol.41, Nos 5/6, 1071-1093 
Table 1 - The Variables Used

\begin{tabular}{|c|c|}
\hline Variables & Method used to construct the variables \\
\hline Innovation & $\begin{array}{l}\text { (a). Number of new product lines introduced } \\
\text { (b). Number of changes/improvements to existing product } \\
\text { lines } \\
\text { (c). Number of new equipment/technology introduced in } \\
\text { the production process } \\
\text { (d). New input materials introduced in the production } \\
\text { process } \\
\text { (e). Number of organisational changes/improvements made } \\
\text { in the production processes } \\
\text { (Scale } 1-7 ; \text { where } 1=\text { Zero, } 2=\text { to } 1-5,3=6-10,4=11 \text { - } \\
15,5=15-25,6=26-50,7=\text { greater than } 50)\end{array}$ \\
\hline Firm Size & $\begin{array}{l}\text { Number of employees } \\
\text { (Scale } 1-7 ; \text { where } 1=\text { less than } 10,2=10-49,3=50-99, \\
4=100-250,5=250-499,6=500-999,7=\text { greater } 1000)\end{array}$ \\
\hline R\&D expenditure & $\begin{array}{l}\% \text { of turnover spent on R\&D } \\
(\text { Scale } 1-5 ; \text { where } 1=1-5 \%, 2=6-10 \%, 3=11-20 \%, 4= \\
21-30 \%, 5=\text { Greater than } 30 \%)\end{array}$ \\
\hline District Affiliation & $\begin{array}{l}\text { Value }=1 \text {, if firm located within North Staffordshire } \\
\text { district } \\
\text { O, otherwise }\end{array}$ \\
\hline Vertical Co-operation & $\begin{array}{l}\text { (a). Improving quality of inputs and final product } \\
\text { (b). New Product designs } \\
\text { (c). Improving delivery times } \\
\text { (d). Marketing and Distribution of products } \\
\text { (e). Labour training } \\
\text { (f). Production organisation } \\
\text { (g). Technological upgrading } \\
\text { (h). Exchange of information/experiences } \\
\text { Scale } 1-5 \text {, where } 1=\text { no co-operation and } 5=\text { Very high } \\
\text { level of co-operation }\end{array}$ \\
\hline Horizontal Co-operation & $\begin{array}{l}\text { (a). New Product Designs } \\
\text { (b). Marketing and Distribution of products } \\
\text { (c).Labour training } \\
\text { (d). Production organisation } \\
\text { (e). Outsourcing production } \\
\text { (f). Technological upgrading } \\
\text { (g). Exchange of information/experiences } \\
\text { Scale } 1-5 \text {, where } 1=\text { no co-operation and } 5=\text { Very high } \\
\text { level of co-operation }\end{array}$ \\
\hline
\end{tabular}


(a). You have received support for $R \& D$ activities from industry and academic institutions

(b). Your firm has received benefits from research activities carried out by industry and academic institutions. (c) In seeking support for your business you are willing to liaise with industry and academic institutions

Scale 1-5, where $1=$ strongly disagree and $5=$ strongly agree 
Table 2: Cronbach's alpha and Bivariate correlations (to two decimal places)

8

\section{9}

10

11

\section{4}

15

1 District

1 gffiliation

1 Onstitutional

2Oupport

2Vertical

22-o-operation

23 Horizontal

25 ooperation

$f=$ Cronbach's alpha for all multiple-item variables

28 IF - Variance Inflation Factor

$29 * *$ Pearson's Correlation is significant at the 0.01 level (2-tailed).

$30 *$ Pearson's Correlation is significant at the 0.05 level (2-tailed).

Pearson's Correlation is significant at the 0.10 level (2-tailed). 
Table 3 Multivariate Analysis: Dependent Variable - Innovation

\begin{tabular}{|c|c|c|c|c|c|c|c|}
\hline & (1) & (2) & (3) & (4) & (5) & (6) & (7) \\
\hline Constant & $\begin{array}{c}1.683 * * * \\
(0.210)\end{array}$ & $\begin{array}{c}1.817 * * * \\
(0.24)\end{array}$ & $\begin{array}{c}1.882 * * * \\
(0.24)\end{array}$ & $\begin{array}{c}1.983 * * * \\
(0.246)\end{array}$ & $\begin{array}{c}1.977 * * * \\
(0.244)\end{array}$ & $\begin{array}{c}1.965^{* * * *} \\
(0.262)\end{array}$ & $\begin{array}{c}1.958 * * * \\
(0.254)\end{array}$ \\
\hline Firm Size & $\begin{array}{c}0.385 * * * \\
(0.065)\end{array}$ & $\begin{array}{c}0.348 * * * \\
(0.068)\end{array}$ & $\begin{array}{c}0.348 * * * \\
(0.068)\end{array}$ & $\begin{array}{c}0.318 * * * \\
(0.070)\end{array}$ & $\begin{array}{c}0.301 * * * \\
(0.070)\end{array}$ & $\begin{array}{c}0.311 * * * \\
(0.092)\end{array}$ & $\begin{array}{c}0.322 * * * \\
(0.089)\end{array}$ \\
\hline R\&D Expenditure & $\begin{array}{c}0.200 * * * \\
(0.075)\end{array}$ & $\begin{array}{c}0.167 * * \\
(0.076)\end{array}$ & $\begin{array}{c}0.168 * * \\
(0.077)\end{array}$ & $\begin{array}{l}0.142 * \\
(0.078)\end{array}$ & $\begin{array}{l}0.135^{*} \\
(0.078)\end{array}$ & $\begin{array}{l}0.110^{*} \\
(0.065)\end{array}$ & $\begin{array}{c}0.106 \\
(0.067)\end{array}$ \\
\hline District Affiliation & $\begin{array}{l}0.400 * * \\
(0.195)\end{array}$ & $\begin{array}{l}0.340^{*} \\
(0.196)\end{array}$ & $\begin{array}{c}0.331 * \\
(0.20)\end{array}$ & $\begin{array}{l}0.328^{*} \\
(0.198)\end{array}$ & $\begin{array}{l}0.367 * \\
(0.198)\end{array}$ & $\begin{array}{c}0.377 \\
(0.247)\end{array}$ & $\begin{array}{c}0.375 \\
(0.244)\end{array}$ \\
\hline $\begin{array}{l}\text { Vertical Co- } \\
\text { operation }\end{array}$ & & $\begin{array}{l}0.189 * \\
(0.114)\end{array}$ & $\begin{array}{l}0.193 * \\
(0.115)\end{array}$ & $\begin{array}{c}0.169 \\
(0.115)\end{array}$ & $\begin{array}{c}0.045 \\
(0.137)\end{array}$ & $\begin{array}{c}0.035 \\
(0.119)\end{array}$ & $\begin{array}{c}0.013 \\
(0.113)\end{array}$ \\
\hline $\begin{array}{l}\text { Horizontal Co- } \\
\text { operation }\end{array}$ & & & $\begin{array}{c}-0.026 \\
(0.090) \\
\end{array}$ & $\begin{array}{l}-0.042 \\
(0.090)\end{array}$ & $\begin{array}{l}-0.059 \\
(0.089)\end{array}$ & $\begin{array}{c}0.088 \\
(0.097)\end{array}$ & $\begin{array}{c}0.087 \\
(0.097) \\
\end{array}$ \\
\hline $\begin{array}{l}\text { Institutional } \\
\text { Support }\end{array}$ & & & & $\begin{array}{l}0.169^{*} \\
(0.099)\end{array}$ & $\begin{array}{l}0.166^{*} \\
(0.098)\end{array}$ & $\begin{array}{l}0.187 * \\
(0.107)\end{array}$ & $\begin{array}{l}0.274 * \\
(0.155)\end{array}$ \\
\hline $\begin{array}{l}\text { Vertical Co- } \\
\text { operation * District } \\
\text { Affiliation }\end{array}$ & & & & & $\begin{array}{l}0.358^{*} \\
(0.218)\end{array}$ & $\begin{array}{c}0.468 * * * \\
(0.163)\end{array}$ & $\begin{array}{c}0.520 * * \\
(0.155)\end{array}$ \\
\hline $\begin{array}{l}\text { Horizontal Co- } \\
\text { operation* } \\
\text { District Affiliation }\end{array}$ & & & & & & $\begin{array}{c}-0.482 * * \\
(0.205)\end{array}$ & $\begin{array}{l}-0.460 * \\
(0.212)\end{array}$ \\
\hline
\end{tabular}




\section{Table 4 Proportion of District Firms Engaging in Horizontal Co-operation}

\begin{tabular}{|l|l|l|l|}
\hline & $\begin{array}{l}\text { All District } \\
\text { Firms }\end{array}$ & $\begin{array}{l}\text { Large Firms } \\
\text { (i.e. greater } \\
\text { than 250 } \\
\text { employees }\end{array}$ & $\begin{array}{l}\text { Small and } \\
\text { Medium Sized } \\
\text { Firms (1-249 } \\
\text { employees) }\end{array}$ \\
\hline District Horizontal Co-operation & $29.7 \%$ & $55.5 \%$ & $24.4 \%$ \\
\hline National Horizontal Co-operation & $14.8 \%$ & $11.1 \%$ & $15.5 \%$ \\
\hline International Horizontal Co-operation & $18.5 \%$ & $55.5 \%$ & $8.9 \%$ \\
\hline
\end{tabular}

Source: Author's Survey

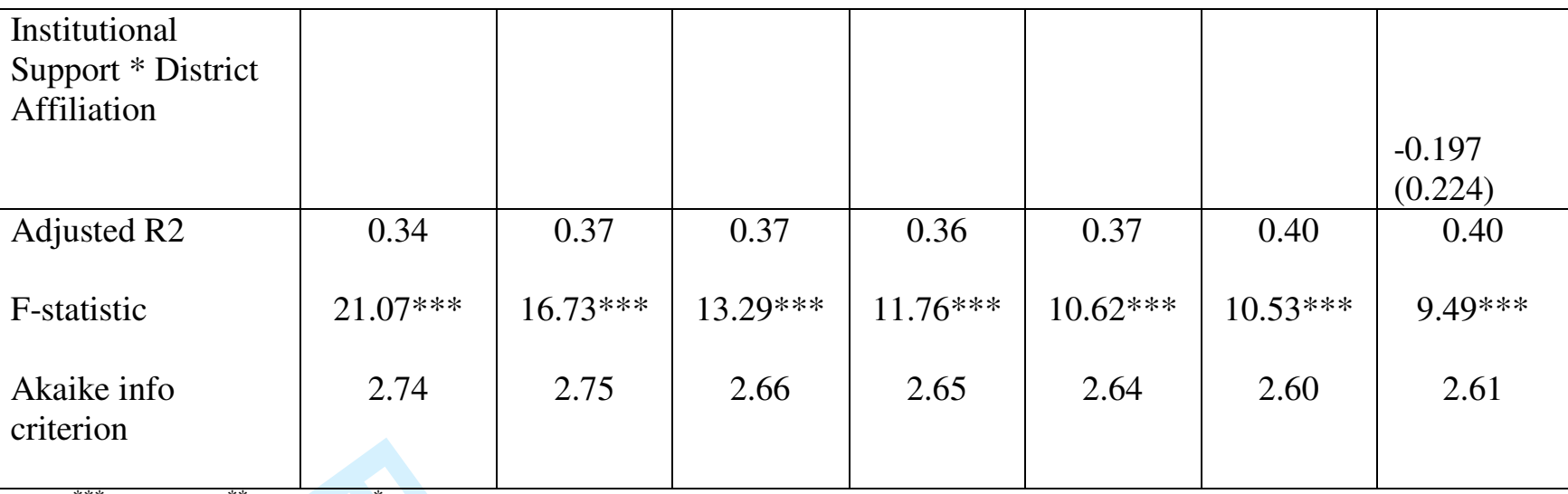

$\mathrm{p}<0.01 ;{ }^{* *} \mathrm{p}<0.05 ;{ }^{*} \mathrm{p}<0.10$, Non-standardized regression coefficients (errors in brackets) 
Appendix: Table A1 - Sample and Population of Firms

\begin{tabular}{lll}
$\begin{array}{l}\text { Number of } \\
\text { Employees }\end{array}$ & $\begin{array}{l}\text { Table and Giftware } \\
\text { Sector }\end{array}$ \\
\hline & Sample & Population \\
$\mathbf{0 - 9}$ & $70.3 \%$ & $75.5 \%$ \\
$\mathbf{1 0 - 4 9}$ & $16.1 \%$ & $14.2 \%$ \\
& & \\
$\mathbf{5 0 - 2 4 9}$ & $5.1 \%$ & $4.2 \%$ \\
& & \\
$\mathbf{7 2 5 0}$ & $8.5 \%$ & $4.1 \%$ \\
Total & $100 \%$ & $100 \%$ \\
\hline
\end{tabular}

Sources: UK Office for National Statistics (2008).

The notional measure of the population is provided by the UK National Office of Statistics (2008), which provides information on the number and proportion of UK firms within a given sector by employment sized bands (1-49, 50-249, greater than 250). 


\section{ENDNOTES}

1 Within European policy circles, such ideas have had a significant influence. For instance, Bougrain and Haudeville (2002) note that innovation policies have increasingly tended to allocate funds towards promoting inter-firm co-operation rather than providing direct subsidies to individual firms. In the UK, such policies continue to permeate current thinking towards innovation (see, for instance, the recent Innovation Report by the UK government's Department for Innovation, Universities and Skills (DIUS, 2008)).

${ }^{2}$ In contrast, there are numerous studies of innovation and collaboration occurring in traditional industries in other European countries. For instance, see Molina Morales and Martinez Fernandez (2006) in relation to 5 Valencian industrial districts (food, textiles, furniture, ceramic tiles and leather), Hervas-Oliver et.al (2008) and Hervas-Oliver and Albors-Garrigos (2009) with regards to ceramic tiles in Castellon, Spain and Sassoulo, Italy, and Boschma and Ter Wal (2007) in the case of the Barletta footwear district in Southern Italy.

${ }^{3}$ Empirically, both Shan et al. (1994) and Ahuja (2000) have found in the US biotech and chemical industries respectively, that the number and range of co-operative ties that a firm establishes is positively correlated with their patent count. More widely in the management literature, the competitive advantage in innovative performance enjoyed by Japanese manufacturers during the 1970s and 1980s was also largely regarded as being based upon their own collaborative (and integrated) supply chain systems (see for instance, Gerlach, 1992; Smitka, 1991; Sako, 1994).

4 In contrast to tacit knowledge, 'codified' knowledge is in the public domain and easily transmitted between firms, irrespective of geography (Sacchetti, 2004).

${ }^{5}$ For instance, in the Barletta footwear district, Boschima and Ter Wal (2007) found that local knowledge externalities were unevenly distributed among local firms, with better performing district firms having a higher absorptive capacity, being better connected and actively participating in local networks.

${ }^{6}$ Jaffe and Trajtenberg (1999) uncover a similar pattern at the national level, with inventors more likely to cite patents originating from their own country than elsewhere.

7 Both De Propris (2002) and Freel and Harrison's studies use categorical variables to capture the variables of interest (innovation and co-operative ties). These omit important information, particularly in relation to the scale and various dimensions of innovation and co-operation; as such, they are unable to say very much about the degree of inter-firm co-operation required for successful innovation. 
${ }^{8}$ Freel and Harrison's (2006) study also showed that links with universities were positively correlated with innovation.

${ }^{9}$ An example in the context of the current study is the British Ceramics Biennial Trade Festival, which is held in the North Staffordshire industrial district and brings together leading ceramic manufacturers, artists and customers from across the globe. This is organised and supported by the West Midlands Regional Development Agency, Stoke on Trent City Council and the main UK ceramics industry institutions, which are all based in North Staffordshire (see Section 3).

${ }^{10}$ The district's hotel-ware companies have taken advantage of changing trends towards 'experience' dining out and increased demands for premium dinner-ware in 'exclusive' restaurants/hotels. In addition, servicing tableware sets is important for hotels/restaurants who want to be assured that broken items can easily and quickly be replaced with similar items from the same product line and of similar (high) quality. The salience of these points was made to one of the authors in a conversation with the (late) Kevin Farrell, who was head of the British Ceramics Confederation, in 2007.

${ }^{11}$ We aware that in identifying district affiliation, Sammarra and Biggiero (2001) propose a focus upon cognitive elements and social interaction between actors; where firms share similar values, norms and trust and recognise their mutual interdependencies, their behaviour towards each other will exhibit group characteristics that define their district membership. These groupings are sometimes difficult to capture in survey work. Such cognitive processes and group formation are however enhanced through physical proximity (and network density). In the case of the North Staffordshire table and giftware industry, firms generally recognise their long held historical and geographical associations within the industrial district (Day et.al 2000, Carroll et.al 2002). It thus seemed appropriate to base the district affiliation upon geographical boundaries.

${ }^{12}$ This is a non-trivial insight, since previous quantitative studies (e.g. De Propris (2002) and Freel and Harrison (2006)), have merely emphasised the existence (and sometimes number) of co-operative ties as being important for innovation, yet have shed little light on the nature of such ties. What is therefore clear from this study is that the nature of the dyad between partner firms in the district industry is particularly important for innovation.

${ }^{13}$ Recently, there have been proposals for a new innovation centre located within the North Staffordshire district, with the aim of linking the existing areas of innovation, knowledge transfer and developing the skillsbase, along with Research and Development (R\&D) across firms and related actors (see SQW, 2009). 